\title{
Enlightenment of Efficient America Agricultural Products Logistics on China's Agricultural Products Logistics Efficiency
}

\author{
Peijing Li
}

School of Business, Luoyang Normal University, Luoyang, 471000, China

\begin{abstract}
Keywords: America. Efficient agricultural products logistics. logistics efficiency
\end{abstract}
\begin{abstract}
Agricultural products logistics is of great significance on the development of national economy. European and American agricultural products logistics industry has been headed globally with a kind of advanced agricultural product logistics operation mechanism. In this paper, the mode of America efficient agricultural products logistics is reviewed, current situation of agricultural products logistics in China is analyzed, and the reference ideas are proposed to improve the efficiency of agricultural products logistics in China according to America efficient agricultural products logistics.
\end{abstract}

\section{Introduction}

There are various reasons for the problem of low developing level and difficult farmer income increasing in China, however, poor circulation of agricultural products is certainly one of the most significant reasons, namely low circulation efficiency, high cost and large loss of agricultural products in China, and the delayed development of circulation industry of agricultural products becomes a key factor affecting circulation efficiency of China's agricultural products. America has an almost 100 years of history on the study of efficient logistics, it has a relatively perfect modern logistics system and high level logistic management, particularly on the agricultural products logistics which is charactered by low cost, high efficiency, small loss and good benefits, no doubt that America efficient agricultural products logistics is of great reference value on the development of agricultural products logistics in China.

\section{Review of America Efficient Agricultural Products Logistics}

\section{Service Principal of America Efficient Agricultural Products Logistics}

The service mechanism in America agricultural society has been relatively perfect, it is charactered by fundamental features such as various form, different levels, serialization and pluralism; production, processing, transportation and marketing of agricultural products are included. Every specific part of the logistics industry, as long as there's demand from farmers, there will be those who are interested in providing logistics services. In general, service principal of agricultural products logistics includes: first, various businessman, mainly includes farm wholesalers, retailers, agents and processors; second, professional sales cooperation organizations which the farmers join in; third, civil association, service organizations spontaneously organized by farmers, not only provide agricultural information service, but also organize processing of similar agricultural products and find sales for their agricultural products; forth, agricultural companies, mainly enterprises which has integrated production, processing and sales, they are the main way the agricultural products entering the market; fifth, government established agricultural credit companies, those companies purchase and reserve quite number of agricultural products according to government acts and contacts to stabilize the market price of local agricultural products, thereby ensuring food security.

\section{Professionalization and Modularization of America Efficient Agricultural Products Logistics}

The production of America agricultural products is well known with their high professionalization and modularization. Their origin market is really concentrated, and the single farmer's production scale is very large, taking large production and circulation as main features. America has witnessed a highly territorialized agricultural production, forms specialized agricultural production areas such as corn, wheat, soybean and fruit. At the same time, the origin market of agricultural production is 
highly concentrated, the production of NY, Washington and Michigan account for about $70 \%$ of the whole nation, and each farm is highly scaled to provide large volume of agricultural products, the scale of production directly led to establishing and perfecting of production organization, continuously improving the control force and extending the control area of production organizations. Direct consumption of agricultural products and the giant demand of agricultural products processing generate a great deal of agricultural trade, and the scale consumption demand of production organization also contributes to scale development of selling enterprise. Driven by the great profit and pressed by the market competition, reducing circulation and cost of logistics have gradually be a choice of enterprise to control the products costs and enhance the market competitiveness besides production costs, management costs and market costs. Because of these factors, America agricultural products logistics operation is dominated by direct selling, nearly $80 \%$ of agricultural production is directly delivered to the retailer through the logistics distribution center, wholesaler sales only $20 \%$. A quite high proportion of direct sales has reduced America sales of agricultural products circulation, increases the efficiency of circulation.

\section{Introduction to the Supporting System of America Efficient Agricultural Products Logistics}

The development of America agricultural products logistics cannot leave the positive regulation of the government. Government is responsible for the development of laws and regulations relating to agricultural product logistics. Almost all of agricultural products circulation is clearly and strictly regulated, so as to effectively safeguard the circulation of agricultural products and enhance the efficiency of circulation. On this basis, America government publish supporting polices on agricultural products, not only attaches great importance to the investment of agricultural researches and the promotion of agricultural techniques, but also attaches great importance to public infrastructure construction needed by agricultural product logistics, government spend $\$ 30$ billion for the construction of transportation infrastructure. America transportation facilities have been quite sophisticated, such as roads, railways and shipping throughout the United States, highways throughout local communities, ensuring the circulation of agricultural products. Today, America has gradually formed an efficient logistics technology system taking modern information technologies as main body; storage and transportation technology ,packaging technology as supporting, especially the full application of cold chain technology utilized in the logistics process which can greatly reduce the attrition rate of agricultural products.

At the same time, America promotes the agricultural informationization construction continuously. Ever since the 90's of the last century, America government allocates $\$ 1.5$ billion annually on the construction of agricultural information network and promotes the application actively. Today, America has established the world's largest computer network system in agriculture. This system nor only covers the United States, but also covers sin provinces in Canada, as well as seven other countries besides USA and Canada. It is connected to the United States Department of Agricultural, 15 State Agricultural Department, 36 universities and a large number of agricultural enterprises. Users can share all kind of information source in the network through various types of terminal equipment such as telephone, televisions or computers, enabling the information source real-time sharing on computer from production, operation to sale, in this way, real-time tracking and whole-process management to all sections of agricultural products logistics can be effectively achieved, information processing and publishing of agricultural products can be implemented, as well as marketing information advisory services.

\section{Current Situation of Agricultural Products Logistics in China}

At present, the participates in logistics of agricultural products in China is of small scale, low hierarchy, discreteness, low joint, as well as low level organization, construction of transaction regulation of agricultural products market is relatively low, standardization of the trade needs to be improved. Following are the main problems in the development of agricultural products logistics: First, too many circulation sections, which brings high transaction costs. Today the logistics system of agricultural products is discrete, low in marketization, inefficient, leads to a very high negative 
cost and social transaction costs during logistics. Second, market signals cannot be known accurately, interests of producer and consumer is damaged. The character of agricultural production decides that the households and families must take the natural risk and market risk at the same time. Because the unclear circulation of agricultural products, the accurate marketing signal could not be obtained, naturally, it is difficult to adjust production in time, so as to avoid great losses. For consumers, they have to bear the consequences of increasing transaction costs. Third, marketing organization is discrete, producer and consumer are isolated, thereby, and it is unfavorable to the improvement of agricultural product quality. The discrete nature of marketing organization have affected not only the forming of large industrial organizations, could not achieve the economic scale of agricultural production, but also influence the quality improvement of agricultural products because the marketing information could not play their function on adjusting production and consumption because of the isolated status between producer and consumer. Forth, single market subjects, unable to form a diversified market. In the circulation of agricultural products, numerous low-organize farmers are facing with fewer buyers, two sides could not compete effectively, the market is at an unequal condition.

\section{Enlightenment of Efficient America Agricultural Products Logistics on China's Agricultural Products Logistics Efficiency}

\section{Achieve regulation function of government through macro-level}

In America efficient agricultural production logistics, to play a positive role in the development of agricultural production logistics, first of all, legal regulations and policies related to the development of logistics industries should be worked out by the government, thereby enhancing the effect of macro-control of the government, speeding up the development of agricultural product logistics. To be more specific, following measures are available: First, encourages the development of innovative agricultural product logistics mechanism on legal regulation and policy levels, so as to reduce the cost of agricultural product logistics process. Second, cultivate large agricultural product logistics enterprises, positively supporting the logistics construction of the agricultural products logistics enterprise and their investment on the circulation and processing of agricultural products, give them preferential tax policies and loan, and devote to the high-efficient logistics facilities construction. Third, reform the administration and logistics operation system in the agricultural products market, coordinating the various regions, industries, local government and the interests of different department, so as to enhance the competitiveness of agricultural products through ensuring the improvement of agricultural product logistics.

\section{Reduce the length of the supply chain to reduce the circulation cost}

In current agricultural product logistics system in China, the maximum supply chain is begin with producer, transported to wholesales and sold to local wholesales market, then shipped to the retailer, namely supermarket, shops or catering business, before finally reached consumers. In this way, four transactions are needed before reaching the consumer's hands, sometimes involves several marketing intermediaries and middlemen, there will be more transaction. After several times transaction, the price increases while the freshness is losing when reaching the consumer after being transported several times, to maintain the water in agricultural products, some unscrupulous middlemen and retailer even soak the products in water, leading to decline in quality.

\section{Introduce more advanced logistics management technologies to improve the agricultural products supply chain}

Centered on information technology of agricultural products logistics, America has modern agricultural products logistics technology system. Therefore, China's agricultural product logistics enterprise should introduce advanced technologies on agricultural product logistics, so as to control the cost of agricultural product logistics to enhance standard of logistics service, among them, focusing on improvement of distribution technology and optimizing and integrating the supply chain management is of great importance, this is the developing direction of agricultural product logistics 
industry in developed nations like America, to which the agricultural product logistics enterprise should pay attention.

\section{Create agricultural products logistics cooperation}

Because of the features such as scattered, small, relatively low centralized of agricultural production in China, governments should actively steer and strive to support the development of intermediary organization, promote the development of agricultural brokers, to emulate American experience on agricultural products; following measures may be taken to develop agricultural products logistics cooperation: first, Use different forms of joint-stock cooperative system to encourage farmers to join together to actively develop logistics cooperation economic organization; second, use various forms such as farmers and companies to achieve the combination and linkages with the help of external force of agricultural products; last, use the regulation power of government and social force to build up regional specialized wholesale market which can coupling production and consumption to guarantee the circulation of agricultural products. To actively upgrade the participation of farmers in the organization and standardization of products circulation; build intermediary organizations of agricultural products circulation; ensure the increase of farmers' income; achieve structure adjustment of agriculture industrialization; accelerate the construction of new way in which the agriculture product circulates.

\section{Achieve institutionalization and standardization of the administration of the agricultural products market.}

Agricultural market management and market order play important role to achieve standardized agricultural market and fair competition among market players. Government takes main responsibility in the market administration. First, improve the market regulation. Based on the specific characteristics of the different types of markets, and develop reasonable rules of market management and to establish more effective for the market operation system. Second, strengthen the law enforcement on the management of agricultural markets; resolutely punish all kinds of acts which disturb the normal order of the market. Third, Improve agricultural product quality standard system, thereby contributing to increased efficiency in farm products logistics.

\section{Pay attention to education and cultivation of agricultural product logistics talents}

Focus on the education and cultivation of agricultural products logistics industry workers to actively cultivate high-level personnel of the developing trend of modern logistics of agricultural products. United States agricultural products logistics workers are usually of a very high quality, but the current development of agricultural product logistics in China is lagging, to a great extent, because the farmers have no awareness of agricultural product logistics, hence the need to increase the intensity of agricultural product logistics talents training continuously.

\section{Conclusion}

To sum up, United States efficient logistics mode of agricultural products have a very successful experience scale, which could be a very useful lessons to improve the efficiency of agricultural product logistics in China. However, since the Sino-American differences in national conditions, United States best practices can only be fully reference, rather than mechanical practicing. In view of this, we must proceed from our actual experience, allowing efficient circulation system of Chinese agricultural products to develop healthily and continuously along a correct path to maximize the efficiency.

\section{Reference}

[1] Wang Yan. Reference of America agricultural products logistics modes in China [J]. Journal of Sichuan University of science and technology, 2008 (10).

[2] Xu Xiaoping. Comparative analysis of Sino-US agricultural products logistics [J]. Reform and strategy, 2009 (9). 
[3] Zhu Kunping. The function of America government in logistics of agricultural products [J]. China Trade,2011 (3).

[4] Bian Shengnan. The successful experience of the development of agricultural products logistics in USA [J].the new rural, 2012（4）.

[5] Dang Hui. Pattern and successful development experience of America agricultural products logistics [J], World agriculture, 2014(4). 